\title{
Recent Major Kimberlite Discoveries in Canada
}

Carlson, J.A. ${ }^{1}$, Kirkley, M.B. ${ }^{1}$, Thomas, E.M. ${ }^{2}$, and Hillier, W.D. ${ }^{3}$

1. BHP Minerals Canada Ltd., \#8 - 1699 Powick Road, Kelowna , British Columbia, Canada

2. Aber Resources Ltd., Suite 930, 355 Burrard Street, Vancouver, British Columbia, Canada

3. Ashton Mining of Canada Inc., Unit 123-930 West $1^{\text {st }}$ Street, North Vancouver, British Columbia, Canada

\section{Introduction}

The future position of Canada as a world class producer of diamonds has been established by construction of the Ekati Diamond Mine in the Northwest Territories. Diamond production from the first pipe, the Panda kimberlite, is slated for late 1998 at a rate of approximately 3.5 million carats per annum. Diamond production from Canada could total more than 10 million carats per year with the addition of the Diavik Lac de Gras operation, which is currently at feasibility stage. Since discovery of the Point Lake pipe in 1991, nearly 200 kimberlites have been found in the Slave Province of the Northwest Territories. A newly discovered diamondiferous kimberlite field, the Buffalo Hills province, is located in north central Alberta (Figure 1). To date, 15 kimberlites have been found in the province (Carlson et al., 1998).

\section{Slave Craton, Northwest Territories}

Kimberlites on the Slave craton of Canada's Northwest Territories are concentrated in the vicinity of Lac de Gras, near the craton's geographic center. The BHP-Dia Met and Diavik properties host the majority of pipes, each with several clusters numbering several tens of pipes. Relatively isolated occurrences of individual pipes or small clusters of a few pipes occur outside this central region. The Slave craton is composed predominantly of granites, migmatite gneisses and metasedimentary schists in three main domains: an ancient crustal domain to the west, a younger juvenile domain to the east, and a central accretionary domain (Helmstaedt, 1996 pers. comm.). Kimberlites are concentrated in the central domain. The discovery of the Lac de Gras kimberlites was based on indicator mineral sampling of glacial materials, followed by ground and airborne magnetic and EM surveys (Fipke et al., 1995). Central Slave craton pipe ages range from approximately $47 \mathrm{Ma}$ to $74 \mathrm{Ma}$ (Davis and Kjarsgaard, 1997). The Lac de Gras kimberlite pipes are dominantly filled by volcaniclastic materials, including pyroclastic ash tuffs, lapilli tuffs, and olivine crystal-rich tuffs, and lesser amounts of epiclastic kimberlite mudstones, siltstones, sandstones and rarely conglomerates. Diatreme and hypabyssal phases are present and in some cases crosscut volcaniclastic kimberlite or, more rarely, hypabyssal phases appear to have completely replaced the diatreme and crater materials within the pipe (Kirkley et al., 1998). Mineralogy of the hypabyssal kimberlites suggests that they are Group I; olivine macrocrysts are set in a groundmass dominated by serpentine and carbonate. Fresh monticellite is common, whereas phlogopite, perovskite, ilmenite and spinel are minor groundmass phases.

Canada's first commercial diamond mine, the Ekati Diamond Mine, is located approximately 25 $\mathrm{km}$ north of Lac de Gras. The mining plan includes the development of five kimberlite pipes over a seventeen-year period. The first pipe to be mined is the Panda pipe, which contains an open pit mining reserve of 12.6 million tonnes at 1.09 carats per tonne with an average diamond value of US\$130 per carat. The Panda pipe occupies a small lake, is nearly circular in plan view, has a surface area of 3.1 hectares and is overlain by 15 to 25 meters of glacial sediments. The pipe is comprised of crater facies kimberlite to a depth of at least 300 meters (Figure 2) and is composed 
mostly of volcaniclastic kimberlite with minor lenses or blocks of kimberlitic mudstone, siltstone and sandstone. $\mathrm{Rb}-\mathrm{Sr}$ systematics on phlogopite macrocrysts indicate an age of $53.2 \pm 3.8 \mathrm{Ma}$ (Collerson, 1995 pers. comm.). The main volcaniclastic constituents include olivine crystal tuffs, lapilli tuff and tuff breccia. Volcaniclastic kimberlite has a distinctive pelletal texture and contains abundant olivine macrocrysts (up to $1 \mathrm{~cm}$ ), garnet, chrome diopside and chromite xenocrysts set in a very fine-grained altered matrix. Panda diamonds exhibit all the common natural crystal shapes, namely octahedra, dodecahedra, cubes, twins (macles), aggregates, and combined forms. Broken stones and fragments are very common. Yellow diamonds are very rare, browns and greys are common, and high quality white dodecahedra and octahedra are present up to the largest diamond sizes recovered to date. In contrast, the cubic fibrous material is mainly confined to the smaller size fractions. It is clear that Panda diamonds represent more than one diamond forming episode and that the diamonds have experienced a range of deformation and resorption, as is common for kimberlite diamond production (Gurney, 1998 pers. comm.).

The Diavik Diamond Project is located approximately 30 kilometers southeast of the Ekati Diamond Mine. Final feasibility studies are being undertaken in 1998 at Diavik to assess the economic potential of four diamond bearing kimberlite pipes designated as A-154 South, A-154 North, A-418 and A-21. Together, the four pipes comprise an estimated resource of 37.3 million tonnes, grading an average of 3.3 carats per tonne. A-154 South, A-154 North and A-418 are located within $1 \mathrm{~km}$ of the proposed development site, while A-21 is located $4.5 \mathrm{~km}$ southwest of this main cluster. Parcels totalling 11,739 carats from A-154 South and 8,275 carats from A-418 have been valued at US\$63/ct and US\$56/ct, respectively. Diamond production is anticipated to commence early in the next century, contingent on the completion of feasibility work and the receipt of mining permits.

The Diavik kimberlites are Eocene ( $\sim 53 \mathrm{ma})$ and form small $(<2 \mathrm{ha})$, steep sided, cone-shaped bodies, hosted within a complex of Archean granitoids and micaceous metasediments. All four pipes are located in a near shore environment in Lac de Gras, capped by deposits of Quaternary till (up to $20 \mathrm{~m}$ thick) and thin veneers of lacustrine sediments. Water depths in the project area range from 4 to 25 meters. Volumetrically, the Diavik pipes are dominated by assemblages of volcaniclastic crater facies kimberlite, including pyroclastic and debris flow sequences (Graham et al., 1998). Minor occurrences of hypabyssal kimberlite form contact intrusions along pipe margins and occur as deep magmatic feeders to the pipes. Mineralogically, the kimberlites consist of primary magmatic phenocrysts and mantle xenocrysts dominated by olivine and lesser amounts of garnet, clinopyroxene and mica, set in a matrix of mud and fine kimberlite ash. A variety of country rock and mantle xenoliths are common but mud-dominated Cretaceous platform sediments comprise the largest proportion of xenoliths by volume. Mud fragments, along with conifer wood fragments, have been observed in crater facies kimberlite at depths in excess of 400 meters.

In addition to the Ekati and Diavik pipes, several other kimberlite discoveries in the Slave Province may have commercial potential.

The 5034 (Kennedy Lake) kimberlite, in the southeastern Slave Province, is an irregularly shaped body with a drill-indicated resource of 20 million tonnes to a depth of 350 meters. A 104 tonne sample indicated the grade of the pipe to be 2.5 carats per tonne at an average value of approximately US\$55 per carat. The 5034 pipe is a hypabyssal facies kimberlite characterized by olivine and lesser orthopyroxene macrocrysts set in a groundmass of serpentine, calcite, apatite, perovskite, chrome spinel, apatite, and other mantle phases (Pell, 1997). Whole rock chemistry of 5034 shows some similarities with both Group II kimberlites and micaceous olivine lamproites 
(Cookenboo, 1996). Isotopic studies on groundmass phlogopite yielded a $\mathrm{Rb}$-Sr isochron of 538.6 $\pm 2.5 \mathrm{Ma}$ (Cambrian) (H. Cookenboo, 1997 pers. comm.).

The Jericho pipe, in north central Slave Province, is an elongate multiphase intrusion. Processing of 9,401 tonnes of an underground bulk sample yielded 10,539 carats of diamonds for an average grade of 1.18 carats per tonne and an assigned value of US\$62 per carat (Cookenboo, 1997). Three distinct phases are recognized in the Jericho (Kopylova and Russell, 1996). The earliest phase is a hypabyssal kimberlite, which forms a precursor dike and satellite pipe. The second phase is represented by diatreme facies kimberlite in two lobes adjacent to the central diatreme kimberlite. The latter comprises the third phase. Incorporated within the kimberlites are well-preserved mantle xenoliths including peridotite, eclogite, and pyroxenite (Kopylova et al., 1996). An age of $172.3 \pm$ $2 \mathrm{Ma}$ (mid-Jurassic), has been assigned to the pipe on the basis of Rb-Sr methods on phlogopite megacrysts (Heaman et al., 1997).

Numerous other kimberlite pipes and dikes have been discovered, but preliminary sample results have not been sufficiently encouraging to warrant large-scale bulk sampling.

\section{Buffalo Hills, Alberta}

The Buffalo Hills kimberlite discoveries are located in north central Alberta (Figure 1) and represent a new Canadian kimberlite province (Carlson et al., 1998). The kimberlites intrude a $\sim 1600 \mathrm{~m}$ thick sequence of dominantly flat-lying Devonian and Cretaceous sedimentary rocks. The Precambrian basement, which has been designated as the Buffalo Hills Terrane, consists predominantly of early Proterozoic high-grade metamorphic rocks.

The Buffalo Hills kimberlites were first detected on a fixed-wing aeromagnetic survey conducted for oil and gas exploration. The dominant features defined by the survey were long-wavelength, but several shallow, high frequency anomalies were also recognized. Investigations of pre-existing seismic profiles in the vicinity of these anomalies revealed very strong diffractions. The unusual signatures suggested that the aeromagnetic anomalies were possibly the result of disruptive intrusives.

Ashton Mining of Canada commenced exploration of the Buffalo Hills Terrane in late 1996. To date the company has discovered 15 kimberlites in the province. Inferred sizes range from $<1$ to $\sim 45$ hectares. Some pipes are covered by variable thicknesses of glacial overburden up to $90 \mathrm{~m}$ deep, however several kimberlites crop out (Figure 3). U-Pb dating of perovskite suggests that the Buffalo Hills kimberlites were emplaced between $86 \pm 3$ and $88 \pm 5 \mathrm{Ma}$. Initial petrological studies of the kimberlites indicate that all material recovered to date is crater facies. Volcanic stratigraphy is dominated by lapilli-bearing olivine crystal tuffs, locally with well-defined, coarse ash to coarse crystal normally graded beds. The Buffalo Hills pipes are considered to be Group I kimberlites on the basis of spinel compositional trends, phlogopite composition and the presence of a classic kimberlitic indicator mineral suite (Carlson et al, 1998).

Evaluation of the diamond potential of the Buffalo Hills kimberlites is in the preliminary stages. Diamonds have been recovered from small $(36-91 \mathrm{~kg})$ core and trench samples of all but three of the fifteen tested pipes. The diamond microcrysts $(<0.5 \mathrm{~mm})$ are predominantly sharp-edged octahedra, macles, and octahedral aggregates. By contrast, the diamond macrocryst population is dominated by tetrahexahedra and resorbed fragments with very rare cubes. Bulk sampling programs will be required to determine viability of this new discovery. 


\section{References:}

Carlson, S.M., Hillier, W.D., Hood, C.T., Pryde, R.P., and Skelton, D.N., 1998, The Buffalo Hills Kimberlite Province, North-central Alberta, Canada: this volume.

Cookenboo, H., 1996, Mineralogy, petrology and possible rock types of the 5034 kimberlite at Kennedy Lake, NWT: Exploration Overview 1996; Northwest Territories Mining, Exploration and Geological Investigations, NWT Geology Division, DIAND, p. 3-7.

Cookenboo, H., 1997, Discovery and evaluation of the Jericho kimberlite pipe in the central Slave craton, northern Canada: NWT Geoscience Forum, p. 25-28.

Davis, W.J., and Kjarsgaard, B.A., 1997, A Rb-Sr isochron age for a kimberlite from the recently discovered Lac de Gras field, Slave Province, Northwest Canada: Journal of Geology, 105, p. 503-509.

Fipke, C.E., Dummett, H.T., Moore, R.O., Carlson, J.A., Ashley, R.M., Gurney, J.J., Kirkley, M.B., 1995, History of the discovery of diamondiferous kimberlites in the Northwest Territories, Canada: Sixth International Kimberlite Conference Extended Abstracts, p. 158-160.

Graham, I., Burgess, J.L., Bryan, D., Ravenscroft, P.J., Thomas, E., Doyle, B.J., Hopkins, R., and Armstrong, K.A., 1998. The Diavik kimberlites - Lac de Gras, Northwest Territories, Canada: this volume.

Heaman, I. M., Kjarsgaard, B., Creaser, R.A., Cookenboo, H.O. and Kretschmar, U., 1997, Multiple episodes of kimberlite magmatism in the Slave Province, North America: Slave-Northern Cordillera Lithospheric Evolution (SNORCLE) Transect and Cordilleran Tectonics Workshop Meeting, University of Calgary, Lithoprobe Report 56, p. 14-17.

Kirkley, M.B., Kolebaba, M.R., Carlson, J.A., Gonzales, A.M., Dyck, D., and Dierker, C., 1998, Kimberlite emplacement processes interpreted from Lac de Gras examples: this volume.

Kopylova, M. and Russell, J.K., 1996, Petrographic and chemical variations within the Jericho kimberlite, NWT: 1996 Exploration Overview, NWT Geological Mapping Division, DIAND, p. 3.24-3.25.

Kopylova, M., Russell, J.K. and Cookenboo, H., 1996, Mantle xenoliths from the Jericho kimberlite, NWT: Constraints on the thermal state of the underlying mantle: 1996 Exploration Overview, NWT Geological Mapping Division, DIAND, p. 3.25-3.26.

Pell, J.A., 1997, Kimberlites in the Slave craton, Northwest Territories, Canada: Geoscience Canada, 24, p. 77-90.

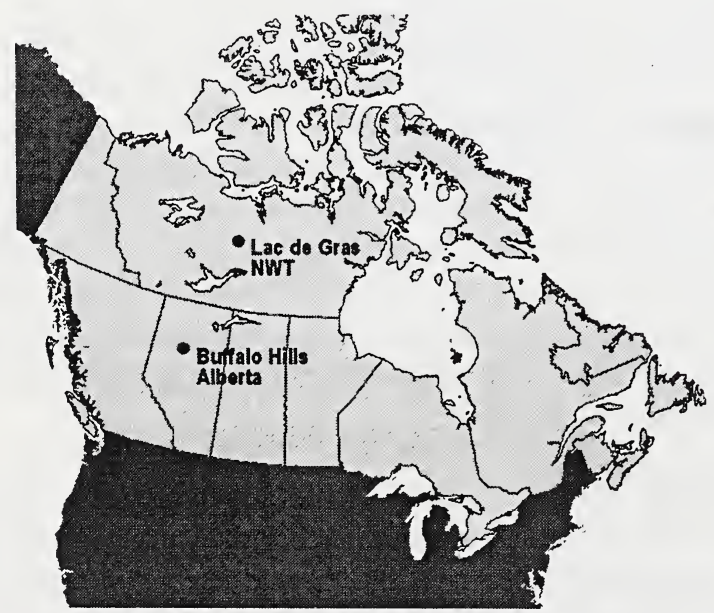

Figure 1. Location map of recent major kimberlite discoveries in Canada 


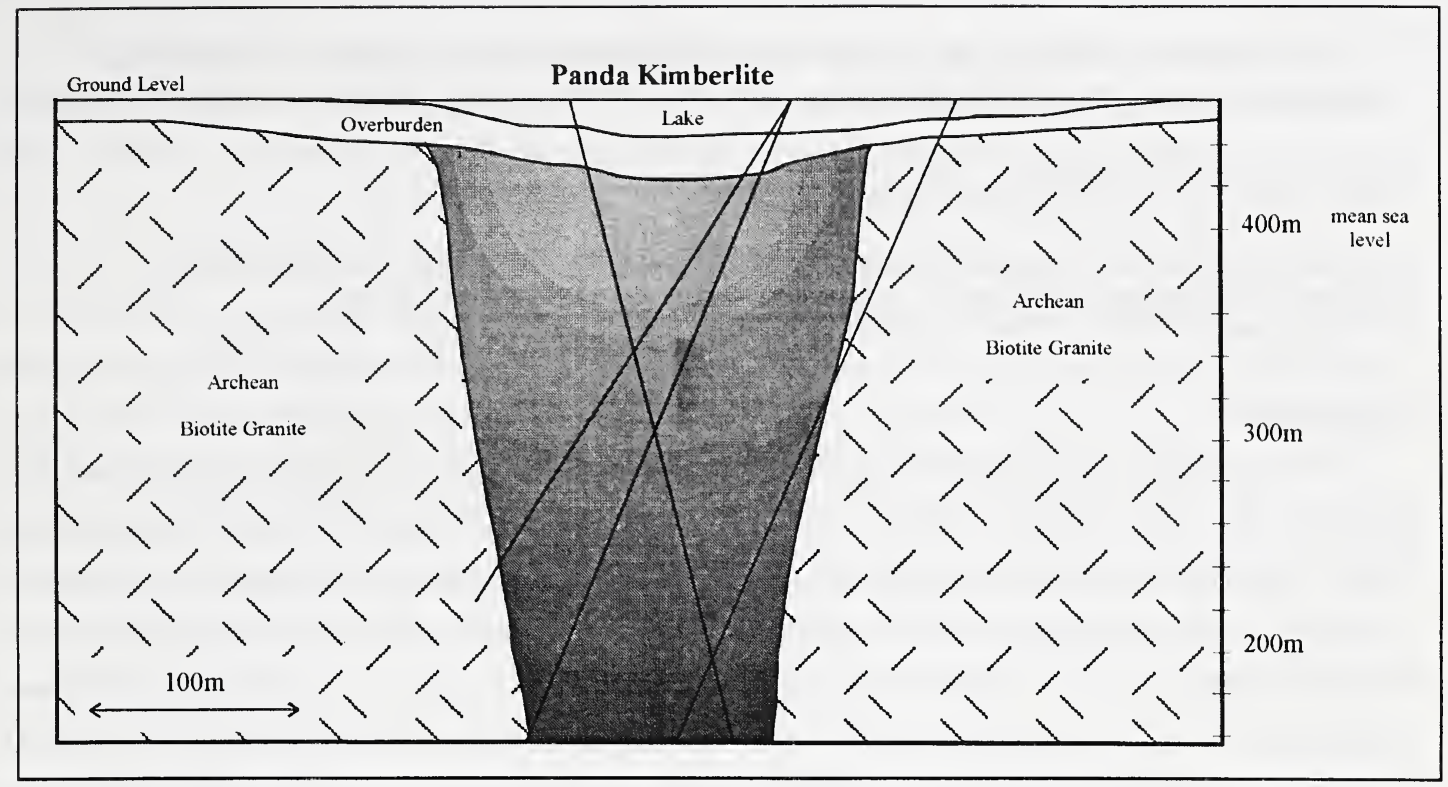

Figure 2. Diagrammatic cross section of the Panda pipe, Northwest Territories

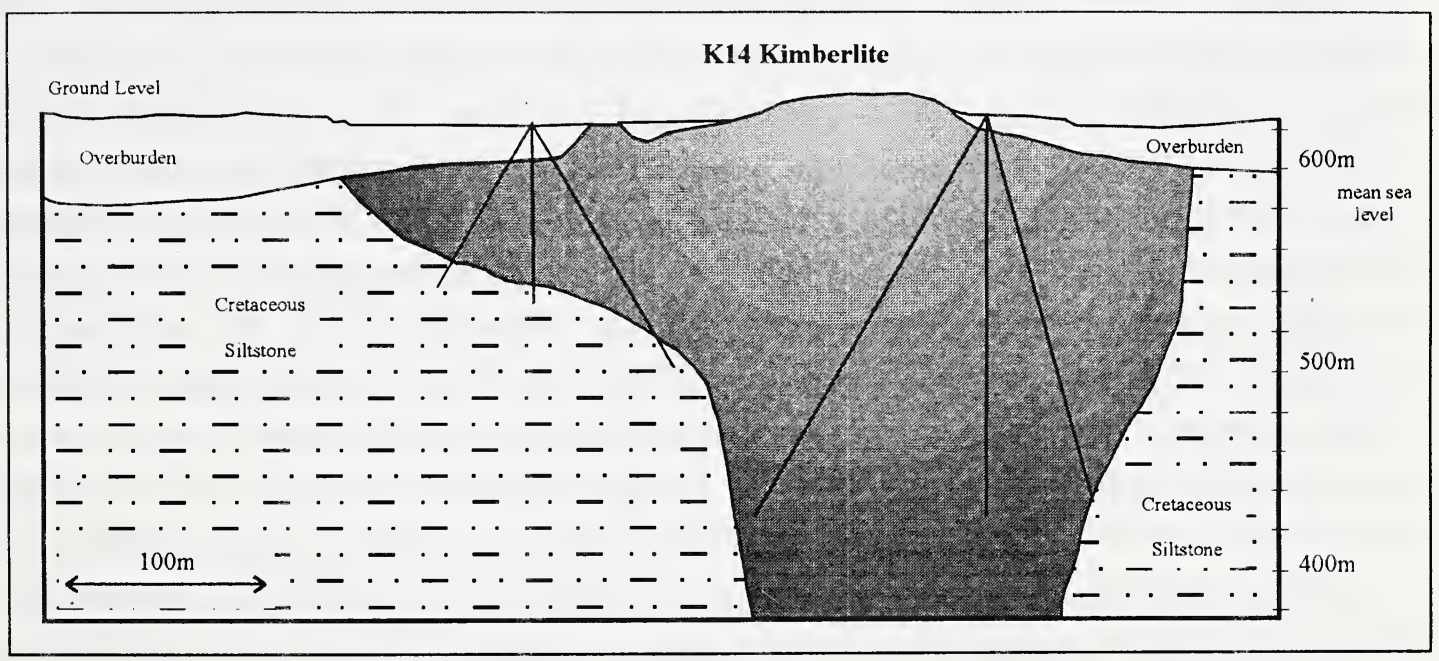

Figure 3. Diagrammatic cross section of the K14 pipe, Buffalo Hills, Alberta 